\title{
Level of acceptance of IUCD insertion in Indian women - a cross-sectional mixed research from central India
}

\author{
Sandhya Subhash Gadre*, Rupa Ahirwar
}

Department of Obstetrics \& Gynaecology Chirayu Medical College \& Hospital, Bhaisakhedi-462003, Bhopal, M.P., India

Received: 26 May 2015

Revised: 30 May 2015

Accepted: 06 June 2015

*Correspondence:

Dr. Sandhya Subhash Gadre,

E-mail: gadre.sandhya@gmail.com

Copyright: () the author(s), publisher and licensee Medip Academy. This is an open-access article distributed under the terms of the Creative Commons Attribution Non-Commercial License, which permits unrestricted non-commercial use, distribution, and reproduction in any medium, provided the original work is properly cited.

\section{ABSTRACT}

Background: In India, knowledge \& awareness of IUCD is inadequate. Many misconceptions are present in the society. Health care providers promote sterilization more than temporary methods or IUCD. The objective was to study the acceptance level of IUCD insertion in Indian women.

Methods: We conducted a cross sectional study in the dept. of Obstertrics \& Gynaecology, Chirayu Medical College \& Hospital, Bhopal on 267 women, interviewing them whether they had accepted IUD in past, if yes continued how long. If no, then causes of non-acceptance found out. They were counseled for IUCD insertion at present. IUCD insertion done for those who were willing. Causes of refusal noted for those who did not accept it. Statistcal analysis of results done.

Results: 113 women were users of temporary contraception, in general they used it for 178 spacings. IUCD was used for $19.10 \%$ of spacings. Out of $267,11.98 \%$ accepted IUCD, $10.48 \%$ in past $\& 1.49 \%$ at present; $88 \%$ did not accept, $\mathrm{p}=0.001$. Continuation was done by $2.62 \%$. Menstrual problem was the commonest reason for discontinuation. From the total, 231 women eligible for IUCD did not accept IUCD in past. 160 eligible women refused IUCD insertion at present.

The difference between temporary \& permanent contraceptives was not statistically significant, $p=0.82$. In the acceptor group, significant difference was found in housewives \& working women, $\mathrm{p}=0.02 \&$ that between BPL card holders \& nonholders, $\mathrm{p}=0.0009$.

Conclusion: IUCD acceptance was very poor in our study. People consult their relatives/friends more than the healthcare providers in this regard, who tend to spread misconceptions. Healthcare providers need to look into the matter seriously. Promotional activities need to be focused on IUCD.

Keywords: IUCD, Acceptance, Nonacceptance, Temporary contraception

\section{INTRODUCTION}

The family welfare program is a priority health program for our country, Inspite of integrated and concerted efforts, the programme has not been able to make an appreciable reduction of Crude Birth Rate ${ }^{1}$. This was mainly because it had almost become synonymous with sterilization. In India the awareness \& knowledge of contraception especially IUCD is inadequate for the purpose it is meant for. Most of the rural \& uneducated women are either not aware of IUCD or they have some misconceptions or unknown fear about their usage. The urban \& educated women have the knowledge about IUCD, but still percentage of these women actually using them is not satisfactory. A general observation regarding this shows that even these women have many misconceptions or fear regarding the same. 
Many studies have been carried out to find out the reasons for discontinuation of contraception, ${ }^{1}$ or studying the factors for acceptance or non-acceptance of contraception in general. ${ }^{2,3}$ Studies on Intrauterine device (IUD) acceptance, its retention and/discontinuation rates are limited $^{1}$

This study aims at analyzing the level of acceptance of Indian ladies towards the use of IUCD specifically. Thus focusing on the importance of good counseling, spreading awareness for IUCD usage, ultimately achieving small family norms \& reducing population explosion, maternal morbidity \& mortality.

\section{General objectives}

To find out $\&$ analyze the level of acceptance of Indian women towards use of IUCD.

\section{Specific objectives}

1. To enhance the awareness about IUCD.

2. To find out the level of willingness of Indian women for using IUCD

3. To provide them proper knowledge \& counseling for the same, alleviate their existing anxieties \& motivate them for utilization of IUCD.

\section{METHODS}

Study design - A Cross-Sectional Mixed Research

Study settings - Chirayu Medical College \& Hospital, Bhopal

Study Period $-15^{\text {th }}$ November $2014-15^{\text {th }}$ May 2015

Study Subjects :- Those who fit into the inclusion criteria $(\mathrm{n}=267)$.

\section{Inclusion criteria}

1. Married women of reproductive age group having minimum one childbirth attending gynaecology OPD $\&$ those admitted in the department who are -

a. reporting for MTP

b. pregnant at present, during antenatal visits to be counseled for postdelivery IUCD insertion.

c. the women admitted for delivery.

d. immediate postpartum \& postabortal

e. lactating mothers

f. not completed families, not using contraception for spacing

g. having completed families, not recently delivered or aborted, not using contraception

h. those who are using other methods of contraception.

2. Women who had undergone tubal ligation were interviewed whether they had accepted IUCD in the past. If not, the causes of non acceptance were analyzed.

3. Women who have had menopause were interviewed whether they had accepted IUCD in the past. If not, the causes of nonacceptance were analyzed.

4. Married nursing staff, lab technicians, clerical staff, attendants working in the hospital, having minimum one childbirth; with parameters a,b,c,d,e,f,g,h, 2,3.

\section{Exclusion criteria}

1. H/o irregular bl pv, menorrhagia, PID, valvular heart diseases

2. Prepubertal girls

This study was conducted in department of Obstetrices \& Gynaecolgy, Chirayu Medical College \& Hospital, Bhaisakhedi, Bhopal from $15^{\text {th }}$ November 2014 to $15^{\text {th }}$ May 2015. The women fitting into the inclusion criteria were interrogated on a pre structured semi -open ended questionnaire. The questionnaire included demographic details, obstetric carrier, use of contraception, the method used, usage of IUCD, its duration for continuation, discontinuation if any, the causes for the same. If no history of IUCD insertion was obtained, then the causes for non-acceptance documented. History of permanent contraception was noted if any. Women eligible for IUCD were counseled for insertion. For those who were willing, IUCD insertion done by electing a date as per patient's physiology. Pilot testing of proforma was done, necessary amendments were implicated. Ethical requirements of informed verbal consent and confidentiality was ensured. Analysis of the answered questionnaire was done.

Statistical aspects - sample size was decided after pilot testing. Chi-square test of significance used for statistical analysis.

Ethical issues - Permission of ethical committee obtained.

\section{RESULTS}

Table 1: Sociodemographic characters of the women under study

(Total no. of Subjects $=267$ )

\begin{tabular}{|lcl|}
\hline Characteristics & No. & $\begin{array}{l}\text { Percentage } \\
(\mathbf{N}=267)\end{array}$ \\
\hline Residence - & & \\
Rural & 52 & 19.48 \\
Urban & 215 & 80.52 \\
\hline Age Distribution - & & \\
(Mean age 33.5 yrs, & \\
SD=10.1) & & \\
$20-29$ & 110 & 41.20 \\
\hline
\end{tabular}




\begin{tabular}{|lcl|}
\hline $30-39$ & 83 & 31.09 \\
$40-49$ & 46 & 17.23 \\
$50-59$ & 23 & 8.61 \\
$60-69$ & 05 & 1.87 \\
\hline Religion- & & \\
Hindu & 243 & 91.01 \\
Muslim & 22 & 08.24 \\
Christian & 02 & 00.75 \\
\hline Education Level- & & \\
Uneducated & 65 & 24.34 \\
Primary & 40 & 14.98 \\
Middle & 85 & 31.84 \\
Secondary & 08 & 03.00 \\
Higher secondary & 04 & 01.50 \\
Graduate & 45 & 16.85 \\
Postgraduate & 20 & 07.49 \\
\hline Income Group- & & \\
BPL card holder & 157 & 58.80 \\
Non holders of BPL & 110 & 41.19 \\
card & & \\
\hline Occupation - & & \\
Majority were & 157 & 58.80 \\
Housewives & & \\
\hline
\end{tabular}

Table 1: Among the study subjects, $80.5 \%$ were urban $\&$ $19.5 \%$ belonged to rural group. Major bulk was formed by 20-39 yrs age group, out of which $41.2 \%$ were of 20 29 yrs \& $31.09 \%$ in 30-39 yrs age. Hindus formed $91 \%$, rest were $9 \% .24 .34 \%$ women were uneducated \& $75.66 \%$ educated, out of which 46.82 had primary or middle school education. 58.80\% women had Below Poverty Line cards, $41.19 \%$ did not have BPL card. Most of the study subjects were housewives $(58.80 \%)$

Table 2: Obstetric behavior of study subjects.

\begin{tabular}{|c|c|c|c|c|c|}
\hline $\begin{array}{l}\text { No. of } \\
\text { Living } \\
\text { Children }\end{array}$ & $\begin{array}{l}\text { No. of } \\
\text { Subjects }\end{array}$ & $\%$ & $\begin{array}{l}\text { No. of } \\
\text { Abortions }\end{array}$ & $\begin{array}{l}\text { No. of } \\
\text { Subjects }\end{array}$ & $\%$ \\
\hline \multirow{2}{*}{1} & \multirow{2}{*}{85} & \multirow{2}{*}{31.84} & None & 190 & 71.10 \\
\hline & & & 1 & 55 & 20.60 \\
\hline 2 & 83 & 31.09 & 2 & 14 & 05.24 \\
\hline 3 & 59 & 22.10 & 3 & 03 & 01.12 \\
\hline 4 & 19 & 07.12 & 4 & 03 & 01.12 \\
\hline 5 & 14 & 05.24 & 6 & 02 & 00.76 \\
\hline 6 & 06 & 02.25 & Total & 267 & 100 \\
\hline 7 & 01 & 00.37 & $\begin{array}{l}\text { No. of } \\
\text { Children } \\
\text { died }\end{array}$ & $\begin{array}{l}\text { No. of } \\
\text { Subjects }\end{array}$ & $\%$ \\
\hline Total & 267 & 100 & None & 247 & 92.50 \\
\hline \multirow{3}{*}{\multicolumn{3}{|c|}{ Mean parity $=2.49, \mathrm{SD}=1.57$}} & 1 & 18 & 6.75 \\
\hline & & & 2 & 02 & 00.75 \\
\hline & & & Total & 267 & 100 \\
\hline
\end{tabular}

Table 2: $31.84 \%$ women had one living child, $31.09 \%$ had 2 living children, $22.10 \%$ had 3 living issues. Mean parity was 2.49 with SD of 1.57 .

$20.60 \%$ subjects had one abortion, $5.24 \%$ had 2 abortions, $1.12 \%$ had 3 abortions \& $1.12 \%$ had 4 abortions. $0.76 \%$ had 6 abortions.

There was h/o death of one child in $6.75 \%$ women $\& \mathrm{~h} / \mathrm{o}$ death of 2 children in $0.75 \%$ women.

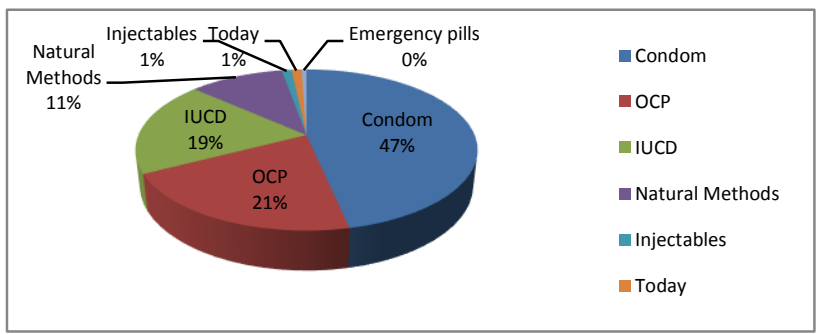

Figure 1: Methods of temporary contraception.

Figure 1: There were 113 women using temporary contraception. Total no. of spacings for which they had used it was 178. Condom was utilized by maximum couples $46.62 \%$ followed by OCPs $20.78 \%$ \& IUCD for $19.10 \%$ of the spacings.

$58 \%$ of condom users used it irregularly, regular users were $42 \%$. Majority of OCP users used it for 1 to 5 cycles, only few used for 3 years of spacing.

*Emergency contraception was used as a regular method of contraception by one study subject.

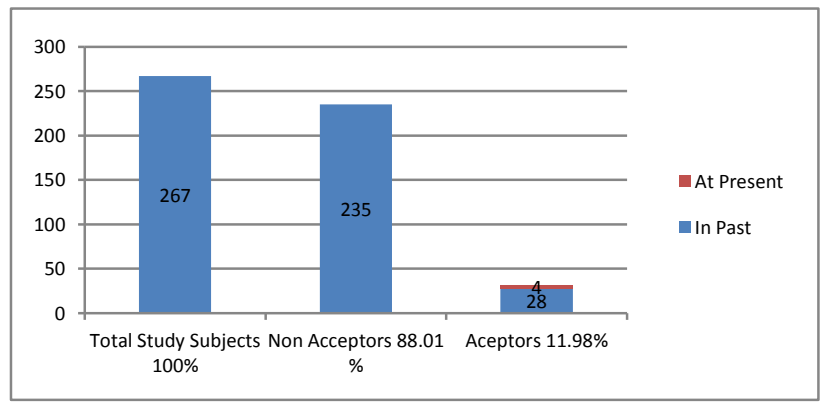

Figure 2: Percentage distribution of IUCD acceptance.

Chart 2: Amongst 267 women, 32 (11.98\%) had accepted IUCD as a method of contraception, $\{28$ women accepted in past $(10.48 \%) \& 4$ women accepted at present $(1.49 \%)$ ); whereas $235(88.01 \%)$ did not accept to opt for IUCD, the difference was statistically highly significant (chi square $=19.15 ; \mathrm{p}=0.001$ ) 


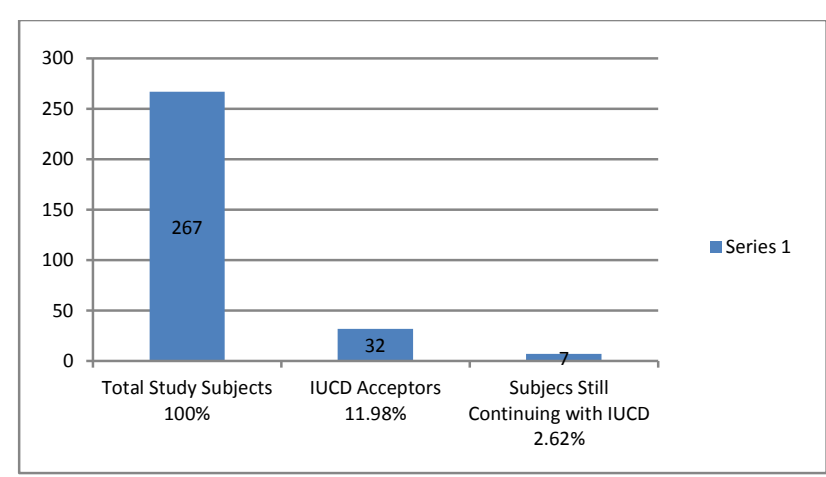

Figure 3: Percentage distribution of IUCD continuation.

Figure 3: from 267 subjects, 32 (11.98\%) accepted IUCD, out of which $7(2.62 \%)$ are still continuing with IUCD. Rest of them discontinued. The duration for which they retained it before discontinuation was 3 days to 1 year. One woman had it for four spacings in a sequence each for 3 years. The last IUCD which she had, she continued with it in situ for 10 years postmenopuse because it was not troubling her !

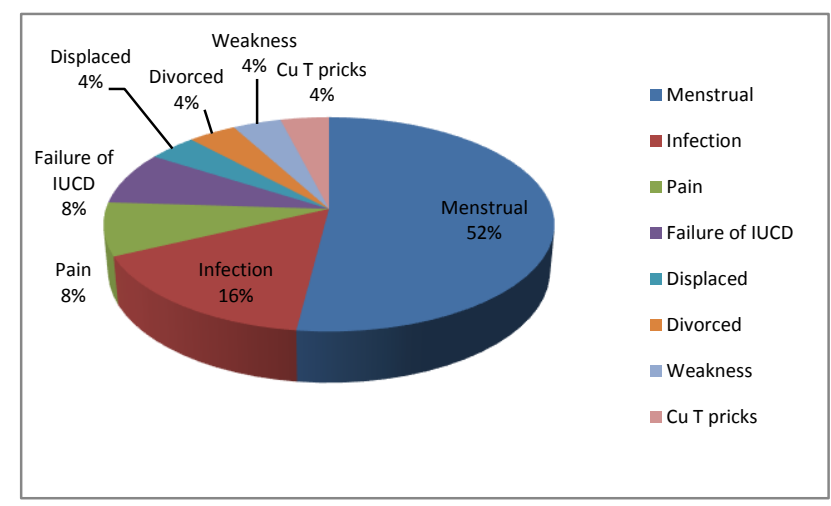

Figure 4: Causes of IUCD discontinuation.

Figure 4: Out of 25 women who discontinued, 13 (52\%) women did so for menstrual reasons; before the due date for removal, 4(16\%) for infection, 2(8\%) each for pain \& failure of IUCD (Pregnancy), 1(4\%) each for displacement, divorce, weakness \& pricking sensation due to $\mathrm{Cu} \mathrm{T}$.

Table 3: Causes for non-acceptance for IUCD in past [231 (86.51 \%) subjects did not accept IUCD in past]

\begin{tabular}{|lcc|}
\hline Causes for Non-acceptance & No. & $\%$ \\
\hline $\begin{array}{l}\text { Not aware that pregnancy can } \\
\text { be avoided. }\end{array}$ & 48 & 17.97 \\
\hline Were using other method. & 31 & 11.61 \\
\hline $\begin{array}{l}\text { Past experience of complications } \\
\text { / trouble / trivial problems in } \\
\text { relatives / friends due to IUCD. }\end{array}$ & 26 & 09.73 \\
\hline Unknown fear. & 21 & 07.86 \\
\hline Did not think it to be necessary. & 20 & 07.49 \\
\hline Although aware of & 18 & 06.73 \\
\hline
\end{tabular}

\begin{tabular}{|c|c|c|}
\hline $\begin{array}{l}\text { contraception, not aware of } \\
\text { IUCD. }\end{array}$ & & \\
\hline No specific answer & 13 & 04.86 \\
\hline $\begin{array}{l}\text { Thought that she will not have } \\
\text { pregnancy even if she did not } \\
\text { use contraception. }\end{array}$ & 06 & 02.24 \\
\hline $\begin{array}{l}\text { Noncooperation / dominance of } \\
\text { husband/mother-in-law. }\end{array}$ & 05 & 01.87 \\
\hline Other causes & 43 & 19.10 \\
\hline $\begin{array}{l}\text { Total no. of women eligible for } \\
\text { IUCD who did not accept } \\
\text { insertion* }\end{array}$ & 231 & 86.51 \\
\hline Total no. of subjects & 267 & 100.00 \\
\hline
\end{tabular}

Table 3: $17.97 \%$ subjects were not aware that pregnancy could be avoided, $11.6 \%$ were using other method, $9.7 \%$ denied IUCD due to past experience of some problems with IUCD in relatives \& friends, $7.49 \%$ did not think it to be necessary. A similar percentage thought that they would not have pregnancy even if no contraceptive was used. In total $86.51 \%$ women who were eligible for IUCD did not accept it. (8 women were nulligravida when past history of IUCD acceptance was considered. 28 women had accepted IUCD. Both these groups are not accounted here for calculation).

Table 4: Causes for refusal for IUCD insertion at present [160 women ( $\mathbf{5 9 . 9 2 \% )}$ refused]

\begin{tabular}{|lll|}
\hline $\begin{array}{l}\text { Causes for Refusal at present } \\
\text { Will get IUCD on } \\
\text { Husband's consent. }\end{array}$ & 23 & 08.61 \\
\hline $\begin{array}{l}\text { Immediate postpartum, } \\
\text { will get insertion after } \\
\text { sometime. }\end{array}$ & 12 & 04.49 \\
(Denied for PPIUCD) & 09 & 03.37 \\
\hline $\begin{array}{l}\text { Will get IUCD with } \\
\text { MTP* }\end{array}$ & 09 & 03.37 \\
\hline $\begin{array}{l}\text { Wants to opt for } \\
\text { tubectomy. }\end{array}$ & 08 & 02.99 \\
\hline Using other method. & 08 & 02.99 \\
\hline $\begin{array}{l}\text { Past experience of } \\
\text { complications / trouble / } \\
\text { trivial problems in } \\
\text { relatives / friends due } \\
\text { to IUCD }\end{array}$ & 08 & 02.99 \\
\hline $\begin{array}{l}\text { Past self-experience of } \\
\text { complications / trouble } \\
\text { due to IUCD }\end{array}$ & 08 & 02.99 \\
\hline Will get IUCD after menses* & 08 & 28.08 \\
\hline Other Causes & 750.92 \\
\hline $\begin{array}{l}\text { Total Eligible women for } \\
\text { IUCD who refused insertion }\end{array}$ & 08.00 \\
\hline Total & 08 & \\
\hline
\end{tabular}


Table 4: $8.61 \%$ women avoided insertion saying that they will get IUCD after husband's consent*, 4.49\% denied for PPIUCD and showed willingness to get it after puerperium*. $3.37 \%$ had early pregnancy, were going for MTP, said that they will get IUCD with MTP*, another $3.37 \%$ gave a reason that they want a tubal ligation in near future. $2.99 \%$ were using other method, $2.99 \%$ were not willing due to past experience of some problems due to IUCD in friends \& relatives. Another $2.99 \%$ who had IUCD insertion in past, did not want it now due to self experience of IUCD problems in past. $2.99 \%$ women promised to come for insertion after menses*.

(* All these women did not report for IUCD in due course of time. This was labelled as refusal) 4 women who had accepted IUCD \& 103 women who already had undergone tubectomy in past are not considered here.

Table 5: Distribution of contraceptive users temporary vs permanent

(Total no. of subjects using contraception $=216$ )

\begin{tabular}{|lclll|} 
Contraception & No. & $\%$ & $\begin{array}{l}\text { Chi } \\
\text { Square } \\
\text { Value }\end{array}$ & $\begin{array}{l}\text { p } \\
\text { value }\end{array}$ \\
\cline { 1 - 3 } Temporary & 113 & 52.31 & & \multirow{2}{*}{0.03} \\
\cline { 1 - 3 } Permanent & 103 & 47.68 & 0.82 \\
\cline { 1 - 3 } Total & 216 & 100.00 & & \\
\hline
\end{tabular}

Table 5: $52.31 \%$ women used temporary methods, whereas $47.68 \%$ went for permanent methods of contraception. The difference between temporary \& permanent contraception was statistically not significant, $\mathrm{p}=0.82$. [51 (19.10\%)] subjects were nonusers of contraception).

Table 6: Relation of education, income \& occupation to acceptance of IUCD.

\begin{tabular}{|c|c|c|c|c|}
\hline $\begin{array}{l}\text { Demographic } \\
\text { Data }\end{array}$ & Acceptors & $\begin{array}{l}\text { Non- } \\
\text { Acceptors }\end{array}$ & $\begin{array}{l}\text { Chi } \\
\text { Square } \\
\text { Value }\end{array}$ & $\begin{array}{l}P \\
\text { value }\end{array}$ \\
\hline HW & 13 & 144 & \multirow{3}{*}{4.95} & \multirow{3}{*}{0.02} \\
\hline Working & 19 & 91 & & \\
\hline Total & 32 & 235 & & \\
\hline $\begin{array}{l}\text { BPL card } \\
\text { holder }\end{array}$ & 12 & 145 & \multirow{3}{*}{6.8} & \multirow{3}{*}{0.0009} \\
\hline $\begin{array}{l}\text { BPL card } \\
\text { Non-holder }\end{array}$ & 20 & 90 & & \\
\hline Total & 32 & 235 & & \\
\hline Rural & 05 & 47 & \multirow{3}{*}{0.3} & \multirow{3}{*}{0.55} \\
\hline Urban & 27 & 188 & & \\
\hline Total & 32 & 235 & & \\
\hline Uneducated & 07 & 58 & \multirow{3}{*}{0.12} & \multirow{3}{*}{0.72} \\
\hline Educated & 25 & 177 & & \\
\hline Total & 32 & 235 & & \\
\hline
\end{tabular}

Table 6: The no. of HW \& working women in acceptors were $13 \& 19$ respectively \& that in non-acceptors were $144 \& 91$ respectively. The difference was statistically significant $(\mathrm{p}=0.02)$. BPL cardholders \& non holders were $12 \& 20$ in acceptor group \& $145 \& 90$ in non- acceptors, difference was statistically highly significant $(\mathrm{p}=0.0009)$. Acceptors in rural \& urbans were $5 \& 27 ; 47$ \& 188 in non-acceptors, difference not significant statistically $(\mathrm{p}=0.55)$. Uneducated \& educated women were $7 \& 25$ in acceptors; $58 \& 177$ in non-acceptors, no significant difference (p-0.72).

\section{DISCUSSION}

There is lack of awareness of contraception ${ }^{2}$ in general which is not satisfactory. Even when they are aware, it is being underutilized. At the same time there are many misconceptions \& false beliefs regarding IUCD, which is responsible for its non-acceptance.

The results show that out of 267 women, 113 were using temporary methods, 103 had got tubal ligation, 51 did not use any contraception.

The acceptance was more in non-holders of BPL card than the card holders, the difference being statistically highly significant $(\mathrm{p}=0.0009)$; acceptance more in working than housewives $(\mathrm{p}=0.02)$ showing the importance of social class \& working status of women giving them more exposure to this knowledge. The acceptance was not signifcantly affected by educational status $(\mathrm{p}=0.72)$ or place of residence (rural/urban) $(\mathrm{p}=0.5)$.

This goes well with the view of other studies that woman's education does not influence her contraceptive. ${ }^{3,4}$

Those subjects who were on reversible contraception, although condom was opted for by most of them, it was irregularly used by $58 \%$ subjects. When we looked for OCPs, it was taken for 1-5 cycles only, by most of them. It indicates that people are not aware of the fact that the reversible contraceptives are to be utilized on regular basis \& for every cycle till pregnancy is planned.

Because of lack of accurate \& up-to-date information, IUCD is underused in some parts of the world ${ }^{4}$ It is very clear that the level of acceptance of IUCD was very poor in our study subjects. Only $11.98 \%$ accepted it as a contraceptive method. $88 \%$ women did not accept it $(\mathrm{p}=$ 0.001 ). Continuation was done by only $21.87 \%$ of those who had accepted it. Major cause for discontinuation was menstrual problems. Even when these problems were trivial, the fear related to these was such that they wanted to "get rid of" the IUCD very soon. The duration for which IUCD was retained was insufficient.

Discussion with the study subjects revealed many causes for the non-acceptance of IUCD in the past, e.g. lack of awareness, use of other methods, past experience of problem in relatives/ friends, or overhearing small troubles with IUCD, unknown fear, and the fact that they "did not think it necessary". 
When women were counselled for IUCD insertion at present, they gave varied reasons for not accepting. Some promised to get it after menses, those who had early pregnancy showed willingness for insertion with MTP, while some said that they will have it after husband's consent, those counselled for PPIUCD avoided it telling they will get it inserted after puerperium. All these ladies never reported for IUCD thereafter, so were labelled as non-acceptors. Few women denied it saying they want to opt for tubectomy \& did not want to go for IUCD even if the procedure was not planned in near future. They used such methods to refuse IUCD because they wanted to "keep a distance from $\mathrm{Cu}$ T" as long as possible. 2.99\% were using other methods, another small bulk had past experience of some IUCD related problems in friends/ relatives or themselves.

Even after accepting $\mathrm{Cu}$ T, $78.12 \%$ got it removed before the due date for removal. Bleeding, the main reason for IUD discontinuation was found to be consistent with previous studies conducted in a similar setting ${ }^{4}$ Duration for which $\mathrm{Cu} \mathrm{T}$ was retained was only 3 days to 1 year.

One woman had used it for four spacings, 3 yrs for each $\&$ continued the fourth insertion for $10 \mathrm{yrs}$ after menopause as she did not have any trouble with it. Women like her should counsel other women around, because antipropoganda is done by many women for IUCD due to very trivial problems also. We have counseled this lady to motivate other women.

Indian people hesitate to consult health professionals for contraception. They rather consult their friends/relatives for this, who spread many misconceptions, especially for IUCD. Hence people are aware about its "problems" much more than the benefits.

Usage of IUCD is low in many developing countries with a majority of women choosing female sterilization for birth control. ${ }^{4-6}$

Use of long term reversible methods is very low or negligible with only $1.7 \%$ of married women using the IUD in India. ${ }^{4}$

Myths and misconceptions regarding side-effects of reversible contraception and vasectomy also contribute to the conviction of women that female sterilization is superior. Provision of free contraception and monetary incentives for their use had limited success in India. ${ }^{6}$

Although it was not the objective of our study, but we observed that the number of women opting for sterilization was not much different than the temporary method users. $(\mathrm{p}=0.82)$. The mean interval between last childbirth \& tubectomy was 1.35 years; suggesting that although they use temporary contraception very less, they opt for tubectomy soon after the family completion. Only one husband had vasectomy done.
If they have not completed their family size \& we counsel them for IUCD, they refuse it on the basis that they will get sterilization after one more child \& that is why they are not willing for IUCD "at this time". Meaning that they want to adapt contraception only when the family is complete, there is no concept of spacing.

Program managers and field-workers are not popularizing reversible methods, and therefore couples are unable to learn about their benefits. A strong commitment from program managers at all levels is needed to increase reversible-method use $^{7}$ in a way they are promoting sterilization.

The belief that there will not be menstruation during lactation, hence no need for contraception during lactation, predominant son preference $\&$ the belief that PPIUCD might hinder their chance for future conception was reason for refusal. ${ }^{8}$

As documented in National Family Health Survey Subject Reports, No. 13, women who discontinued contraception did so because of a method-related problem or method failure. $15 \%$ of women who do not use contraception and who do not intend to use contraception in the future report method-related problems as their main reason for not intending to use contraception. These findings suggest that the quality of family planning services in India needs improvement ${ }^{9}$

\section{CONCLUSION}

The acceptance of IUCD is very poor in Indian women which is a matter of great concern \& needs to be seriously handled by health professionals.

\section{Suggestions}

1. The incentive given by the govt should be the same for IUCD \& sterilization. (There is a provision for incentive to motivator of PPIUCD only, which is lesser than that for tubectomy, no incentive is given to motivator of interval IUCD!)

2. In order to make the IUCD more acceptable, govt organizations can popularize IUCD usage through celebrities \& take benefit of their popularity, as Indian people like to follow the advices/suggestions given by these persons.

\section{Funding: No funding sources \\ Conflict of interest: None declared \\ Ethical approval: The study was approved by the Institutional Ethics Committee}

\section{REFERENCES}

1. Biswas R, Nandy S, Mitra K, Mandal PK, Ray S, Biswas AB. Profile of IUD Acceptors Attending Post 
Partum Unit of a Teaching Hospital. Indian Journal of Community Medicine. 2002;27(3):130-5.

2. Thapa S, Rani A, Mishra CP. Knowledge, attitude and belief about contraception in post-partum and post abortal women in a tertiary care centre. Int $\mathrm{J}$ Reprod Contracept Obstet Gynecol. 2014;3(3):533-9.

3. Moursund A, Kravdal O. Individual and community effects of women's education and autonomy on contraceptive use in India. Popul Stud (Camb). 2003;57(3):285-301.

4. Azmat SK, Hameed W, Mustafa G, Hussain W, Ahmed A, Bilgrami M. IUD discontinuation rates, switching behavior, and user satisfaction: findings from a retrospective analysis of a mobile outreach service program in Pakistan. International Journal of Women's Health. 2013;5:19-27.

5. Ambadekar NN, Rathod KZ, Zodpey SP. Study of $\mathrm{Cu} \mathrm{T}$ utilization status and some of the factors associated with discontinuation of $\mathrm{Cu} \mathrm{T}$ in rural part of Yavatmal district. Indian $\mathrm{J}$ community Med. 2011;36(1):54-6.

6. Ann M, Hall K, Stephenson RB, Juvekar S. Social and Logistical Barriers to the Use of Reversible
Contraception among Women in a Rural Indian Village. J Health Popul Nutr. 2008;26(2):241-50.

7. Rajaretnam T, Deshpande RV. Factors inhibiting the use of reversible contraceptive methods in rural south India. Stud Fam Plann. 1994;25(2):111-21.

8. Sanskriti P, Amita T, Pratima M, Rupali D, Jyotsna S, Kumar A. Exploring reasons behind Low acceptance for PPIUCD in postnatal women. New Indian Journal of Surgery. 2011;2(4):246.

9. International Institute for Population Sciences Mumbai, India East-West Center, Population and Health Studies Honolulu, Hawaii, U.S.A. Reasons for Discontinuing and not Intending to Use Contraception in India National Family Health Survey Subject Reports Number 13 Available at http://www.eastwestcenter.org/sites/default/files/file manager/Research_Program/NFHS_Subject_Reports /subj-13.pdf June 1999.

Cite this article as: Gadre SS, Ahirwar R. Level of acceptance of IUCD insertion in indian women - a cross-sectional mixed research from central India. Int J Reprod Contracept Obstet Gynecol 2015;4:107985. 